\title{
HUBUNGAN PERAN PETUGAS KESEHATAN DAN DUKUNGAN KELUARGA DENGAN TINGKAT KEPATUHAN MINUM OBAT PADA PENDERITA TUBERKULOSIS (TB) PARU BTA POSITIF DI WILAYAH KERJA UPT. PUSKESMAS MARTAPURA 1
}

Relationship of The Role of Health Officers and Family Support with The Level Of Compliance with Drug in Positive Fungus Tuberkulosis (TB) in The Working Area of Upt Martapura Health Center 1

Netty, Kasman, Selly Dwi Ayu

Fakultas Kesehatan Masyarakat UNISKA MAB Banjarmasin

Email :netty.sugiono@yahoo.com

\begin{abstract}
One effort to cure pulmonary TB is highly dependent on patient compliance to take medication and seek treatment regularly, as TB treatment adherence is crucial in reducing $T B$ transmission and reducing the number of pulmonary tuberculosis cases in the community. The purpose of this study was to determine the relation between the role of health officer and family support with the level of medication adherence in the positive pulmonary tuberculosis (TB) patient in the working area of UPT. Puskesmas Martapura 1. Data analysis used univariate analysis and Chi Square test on bivariate analysis. The results of the study were the percentage of respondents who were obedient (65.9\%), non-compliant (34.1\%), the role of health workers in good category (81.8\%), the role of health workers in the poor category (18.2\%), support families in the good support category (70.5\%) and lack of support $(29.5 \%)$. The results of the study were the relationship between the role of health workers ( $P$ value $=0.001)$ and family support $(P$ value $=0.019)$ with the level of adherence to taking medication in patients with positive smear pulmonary TB in the UPT. Martapura Health Center 1. It is recommended to involve families during TB treatment and health worker surveys if patients do not come for treatment so that the spread of TB disease can be prevented.
\end{abstract}

Keywords : Role of Health Officers, Family Support, Compliance in Taking Drugs

\begin{abstract}
Abstrak
Salah satu upaya penyembuhan TB paru sangat tergantung dengan kepatuhan penderita untuk minum obat dan berobat secara teratur, karena kepatuhan pengobatan TB merupakan hal yang sangat penting dalam mengurangi penularan TB dan mengurangi angka kasus TB paru di masyarakat. Tujuan penelitian adalah untuk mengetahui hubungan peran petugas kesehatan dan dukungan keluarga dengan tingkat kepatuhan minum obat pada penderita tuberkulosis (TB) paru BTA positif di wilayah kerja UPT. Puskesmas Martapura 1.

Analisis data menggunakan analisis univariat dan uji Chi Square pada analisis bivariat. Hasil penelitian persentase responden yaitu patuh $(65,9 \%)$, tidak patuh $(34,1 \%)$, peran petugas kesehatan kategori baik $(81,8 \%)$, peran petugas kesehatan kategori kurang $(18,2 \%)$, dukungan keluarga kategori dukungan baik $(70,5 \%)$ dan dukungan kurang $(29,5 \%)$. Hasil penelitian terdapat hubungan antara peran petugas kesehatan $(\mathrm{P}$ value $=0,001)$ dan dukungan keluarga $(P$ value $=0,019)$ dengan tingkat kepatuhan minum obat pada penderita tuberkulosis $(\mathrm{TB})$ paru BTA positif di UPT. Puskesmas Martapura 1. Disarankan melibatkan keluarga selama pengobatan TB dan petugas kesehatan survei jika penderita tidak datang berobat agar penyebaran penyakit TB dapat dicegah..
\end{abstract}

Kata Kunci : Peran Petugas Kesehatan, Dukungan Keluarga, Kepatuhan Minum Obat 


\section{PENDAHULUAN}

Tuberkulosis paru merupakan penyakit menular langsung yang disebabkan oleh kuman tuberkulosis (Mycobacterium Tuberculosis). Gejala utama adalah batuk selama 2 minggu atau lebih, batuk disertai dengan gejala tambahan yaitu dahak, dahak bercampur darah, sesak nafas, badan lemas, nafsu makan menurun, berat badan menurun, malaise, berkeringat malam hari tanpa kegiatan fisik, demam lebih dari 1 bulan. Penyakit TB paru ditanyakan pada responden untuk kurun waktu $\leq 1$ tahun berdasarkan diagnosis yang ditegakkan oleh tenaga kesehatan melalui pemeriksaan dahak, foto toraks atau keduanya. (Riskesdes, 2013).

Berdasarkan Data dan Informasi Profil Kesehatan Indonesia tahun 2016 di Kalimantan Selatan, menurut jumlah kasus baru tuberculosis paru BTA positif sebesar 2.811 kasus dengan jumlah lakilaki sebanyak 1.733 kasus dan perempuan sebanyak 1.078 kasus dan menurut kelompok umur, jumlah kasus baru TB paru BTA positif tahun 2016 yang paling banyak terdapat pada kelompok umur 45 - 54 tahun dengan total $19,82 \%$, pada jumlah kasus baru dan kasus kumulatif AIDS dengan jumlah kumulatif tahun 1987 - 2016 sebesar 429 kasus sedangkan hasil cakupan penemuan kasus penyakit tuberculosis. Menurut provinsi Kalimantan Selatan tahun 2016 yaitu besar angka Case Notification Rate (CNR) pada semua kasus sebesar 127 kasus dan BTA positif sebesar 69 kasus. Menurut cakupan TB paru BTA positif sembuh sebesar 82,6 \%, pengobatan lengkap sebesar 5,3\%, dan angka keberhasilan pengobatan sebesar 87,9 \% dari keseluruhan jumlah kasus BTA positif sebesar 3.127 per 188.300 kasus BTA positif di Indonesia. (Data dan Informasi Profil Kesehatan Indonesia Tahun 2016).

PMO merupakan komponen DOT (Directly Observed Treatment) yang berupa pengawasan langsung menelan obat pasien TB oleh seorang PMO, dengan tujuan untuk memastikan pasien menelan semua obat yang dianjurkan. Orang yang menjadi PMO dapat berasal dari petugas kesehatan, kader, guru, tokoh masyarakat, atau anggota keluarga. (Peraturan Mentri Kesehatan Republik Indonesia 67 Tahun 2016 Tentang Penanggulangan Tuberkulosis).
Peran keluarga sebagai Pengawas Menelan Obat sangat diperlukan untuk menjamin kepatuhan pasien menelan obat. PMO sangat dibutuhkan pada tahap intensif (awal) pasien mendapat obat setiap hari dan diawasi langsung untuk mencegah terjadinya kekebalan (resistensi) terhadap semua OAT (Obat Anti Tuberkulosis) terutama Rifampisin. (Snewe F, 2002).

Penelitian Eliska (2005) yang menyatakan faktor pelayanan kesehatan yaitu penyuluh kesehatan mempunyai pengaruh yang bermakna terhadap tingkat kepatuhan berobat penderita TB Paru. Penelitian Dermawanti (2014) menunjukan bahwa sikap mendukung petugas kesehatan memberi pengaruh terhadap kepatuhan pasien dimana pasien mendapat dukungan motivasi dari petugas kesehatan untuk selalu tepat waktu mengambil obat ke Puskesmas dan selalu memperhatikan perkembangan kesehatan pasien, sehingga pasien merasa diperhatikan oleh petugas dan menerima semua anjuran petugas selama pengobatan.

\section{BAHAN DAN METODE}

Penelitian ini merupakan studi analitik atau penelitian kuantitatif dengan pendekatan cross sectional, yang bertujuan untuk meneliti hubungan antara variabel terikat (dependent variable) terhadap variabel bebas (independent variable) dalam waktu yang bersamaan atau point time approach (Notoatmodjo, 2010). Penelitian ini bertujuan untuk melihat hubungan peran petugas kesehatan dan dukungan keluarga dengan tingkat kepatuhan minum obat pada penderita TB paru BTA positif di wilayah kerja UPT. Puskesmas Martapura 1. Lokasi penelitian dilakukan di wilayah kerja UPT. Puskesmas Martapura 1 Kabupaten Banjar. Penelitian dilaksanakan mulai tanggal 10 Mei 2018 sampai dengan 20 Mei 2018.

Teknik pengambilan sampel dengan menggunakan nonprobability sampling yaitu sampel jenuh (total sampling), yaitu jumlah sampel sama dengan populasi. Berdasarkan metode yang ditentukan, maka seluruh penderita TB paru BTA $(+)$ diwilayah kerja UPT. Puskesmas Martapura 1 yaitu dari bulan Oktober tahun 2017 sampai dengan bulan 
Juni tahun 2018 yaitu sebanyak 44 orang. Penelitian ini menggunakan instrument kuesioner dengan cara wawancara secara langsung kepada penderita TB paru BTA $(+)$ di wilayah kerja UPT. Puskesmas Martapura 1. Metode pengambilan data dibagi 2 yaitu data primer yang diperoleh dari data identitas responden, karakteristik responden, kepatuhan minum obat, peran petugas kesehatan, dan dukungan keluarga dengan cara wawancara menggunakan kuesioner. Data sekunder diperoleh dari UPT. Puskesmas Martapura 1 yang diambil dari data geografi dan demografi dengan cara diambil dari data-data berupa laporan tahunan dan laporan bulanan P2 TB paru. di wilayah kerja UPT. Puskesmas Martapura 1. Analisis data menggunakan univariat dan bivariat untuk mengetahui hubungan peran petugas kesehatan dan dukungan keluarga dengan tingkat kepatuhan minum obat pada penderita Tuberkulosis (TB) paru BTA positif diwilayah kerja UPT. Puskesmas Martapura 1.

\section{HASIL DAN PEMBAHASAN}

Responden dalam penelitian ini adalah penderita TB paru BTA positif yang datang berobat di wilayah kerja UPT. Puskesmas Martapura 1 pada bulan Oktober tahun 2017 sampai dengan bulan Juni 2018 berjumlah 44 responden dan bersedia menjadi responden.

\section{Analisis Univariat}

Berdasarkan tabel 1 hasil penelitian menunjukkan bahwa tingkat kepatuhan minum obat yaitu patuh sebanyak 29 responden $(65,9 \%)$, dan tidak patuh sebanyak 15 responden (34,1\%). Kepatuhan adalah perilaku sesuai aturan dan berdisiplin. Seseorang dikatakan patuh berobat bila mau datang kepetugas kesehatan yang telah ditentukan sesuai dengan jadwal yang ditetapkan serta mau melaksanakan apa yang dianjurkan oleh petugas termasuk kepatuhan dalam minum obat. (Suparyanto, 2010). Keteraturan minum obat merupakan tindakan penderita meminum obat TB secara teratur untuk kesembuhan terutama untuk memutuskan rantai penularan, keteraturan minum obat dapat dikategorikan teratur apabila minum obat hari berturut-turut pada fase lanjutan ( 4 bulan). Tidak teratur apabila penderita lalai atau lupa minum OAT
Tabel 1.Distribusi Frekuensi Variabel Penelitian

\begin{tabular}{lcc}
\hline Karakteristik & $\mathbf{n}$ & $\mathbf{\%}$ \\
\hline $\begin{array}{l}\text { Kepatuhan Minum } \\
\text { Obat }\end{array}$ & & \\
\hline$\quad$ Patuh & 29 & 65,9 \\
\hline$\quad$ Tidak Patuh & 15 & 34,1 \\
\hline $\begin{array}{l}\text { Peran Petugas } \\
\text { Kesehatan }\end{array}$ & \\
\hline$\quad$ Baik & 36 & 81,8 \\
\hline$\quad$ Kurang & 8 & 18,2 \\
\hline Dukungan Keluarga & & \\
\hline$\quad$ Dukungan Baik & 31 & 70,5 \\
\hline$\quad$ Dukungan Kurang & 13 & 29,5 \\
\hline Total & $\mathbf{4 4}$ & $\mathbf{1 0 0}$ \\
\hline
\end{tabular}

tidak pernah lalai atau lupa minum OAT selama 14 hari berturut-turut pada fase awal ( 2 bulan) dan 14 selama 14 hari berturut-turut fase awal dan pada fase lanjutan.

Hasil penelitian menunjukkan bahwa sebanyak 36 responden $(81,8 \%)$ menyatakan peran petugas kesehatan dengan kategori baik dalam melaksanakan tugasnya dan sebanyak 8 responden $(18,2 \%)$ menyatakan peran petugas kesehatan dengan kategori kurang dalam melaksanakan tugas pengobatan TB paru. Peran petugas kesehatan adalah suatu kegiatan yang diharapkan dari seorang petugas kesehatan yang memberikan pelayanan kesehatan kepada masyarakat untuk meningkatkan derajat kesehatan masyarakat. Perannya dalam kesehatan sangat dibutuhkan, untuk itu petugas kesehatan harus mampu memberikan kondisi yang dapat mempengaruhi perilaku positif pasien terhadap kesehatannya dengan sebagai komunikator, sebagai motivasi, sebagai fasilitator dan sebagai konselor. (Potter dan Perry, 2007).

Hasil penelitian menunjukkan bahwa sebanyak 31 responden $(70,5 \%)$ menyatakan dukungan keluarga baik tetapi masih ada 13 responden (29,5\%) menyatakan dukungan kurang.

Keluarga sebagai sumber dukungan sosial dapat menjadi faktor kunci dalam penyembuhan pasien. Walaupun keluarga tidak selalu merupakan sumber positif dalam kesehatan klien, mereka paling sering menjadi bagian penting dalam penyembuhan. (Kumfo dalam Videbeck, 2008). Dukungan keluarga 
Tabel 2. Hubungan Peran Petugas Kesehatan dengan Tingkat Kepatuhan Minum Obat Pada Penderita Tuberkulosis (TB) Paru BTA Positif di Wilayah Kerja UPT. Puskesmas Martapura 1

Tingkat Kepatuhan Minum Obat

\begin{tabular}{|c|c|c|c|c|c|c|c|}
\hline \multirow{3}{*}{ Peran Petugas Kesehatan } & & \multirow{2}{*}{\multicolumn{2}{|c|}{ Jumlah }} & \multirow{3}{*}{ P Value } \\
\hline & \multicolumn{2}{|c|}{ Patuh } & \multicolumn{2}{|c|}{ Tidak Patuh } & & & \\
\hline & $\mathbf{n}$ & $\%$ & $\mathbf{N}$ & $\%$ & $\mathbf{N}$ & $\%$ & \\
\hline Baik & 28 & 77,8 & 8 & 22,2 & 36 & 100 & \multirow[t]{3}{*}{0,001} \\
\hline Kurang & 1 & 12,5 & 7 & 87,5 & 8 & 100 & \\
\hline Total & 29 & 65,9 & 15 & 34,1 & 44 & 100 & \\
\hline
\end{tabular}

Tabel 3. Hubungan Dukungan Keluarga dengan Tingkat Kepatuhan Minum Obat Pada Penderita Tuberkulosis (TB) Paru BTA Positif di Wilayah Kerja UPT. Puskesmas Martapura 1

\begin{tabular}{|c|c|c|c|c|c|c|c|}
\hline \multirow{3}{*}{ Dukungan Keluarga } & \multicolumn{4}{|c|}{ Tingkat Kepatuhan Minum Obat } & \multirow{2}{*}{\multicolumn{2}{|c|}{ Jumlah }} & \multirow{3}{*}{ P Value } \\
\hline & \multicolumn{2}{|c|}{ Patuh } & \multicolumn{2}{|c|}{ Tidak Patuh } & & & \\
\hline & $\mathbf{n}$ & $\%$ & $\mathbf{n}$ & $\%$ & $\mathbf{N}$ & $\%$ & \\
\hline Dukungan Baik & 24 & 77,4 & 7 & 22,6 & 31 & 100 & 0,019 \\
\hline Dukungan Kurang & 5 & 38,5 & 8 & 61,5 & 13 & 100 & \\
\hline Total & 29 & 65,9 & 15 & 34,1 & 44 & 100 & \\
\hline
\end{tabular}

diberikan berupa dukungan sosial yaitu dukungan emosional, instrumental, penghargaan, dan informasi. Dukungan keluarga merupakan salah satu peran Pengawas Minum Obat (PMO) karena dapat mempengaruhi pasien patuh untuk minum obat anti tuberkulosis dengan adanya partisipasi dari dukungan keluarga maka dapat mempengaruhi perilaku pasien untuk patuh minum obat sehingga pengobatan dapat tercapai hingga pasien dinyatakan sembuh.

\section{Analisis Bivariat}

Hubungan Peran Petugas Kesehatan Hubungan Peran Petugas Kesehatan dengan Tingkat Kepatuhan Minum Obat Pada Penderita Tuberkulosis (TB) Paru BTA Positif di Wilayah Kerja UPT. Puskesmas Martapura 1

Berdasarkan tabel 2 didapatkan bahwa proporsi peran petugas kesehatan dengan kategori baik berjumlah 36 responden termasuk kategori patuh minum obat sebanyak 28 responden $(77,8 \%)$ dan tidak patuh sebanyak 8 responden $(22,2 \%)$. Proporsi peran petugas kesehatan dengan kategori kurang berjumlah 8 responden termasuk kategori patuh minum obat sebanyak 1 responden $(12,5 \%)$ dan tidak patuh sebanyak 7 responden $(87,5 \%)$.
Hasil analisa uji chi square diperoleh nilai $\mathrm{p}=$ $0,001<a=0,05$ pada tingkat kepercayaan 95\% maka menunjukkan bahwa ada hubungan antara peran petugas kesehatan dengan tingkat kepatuhan minum obat TB paru BTA positif di wilayah kerja UPT. Puskesmas Martapura 1. Menurut penelitian yang dilakukan oleh Sugiono (2014) di wilayah kerja Puskesmas Sepauk Kabupaten Sintang Tahun 2014 tentang faktor-faktor yang berhubungan dengan tingkat kepatuhan mengkonsumsi obat pada penderita Tuberkulosis Paru didapatkan hasil uji statistik $\mathrm{P}$ value $=0,000<a=0,05$ artinya ada hubungan yang signifikan antara dukungan tenaga kesehatan dengan tingkat kepatuhan mengkonsumsi obat TB pada penderita TB paru di Puskesmas Sepauk Kabupaten Sintang Tahun 2014.

Menurut Penelitian yang dilakukan oleh Desy Rindra Puspita (2015) didapatkan hasil uji statistik P value $=0,002<\alpha=0,05$ artinya ada hubungan yang signifikan antara Pengawas Minum Obat terhadap kesembuhan pada pasien TBC di Wilayah Kerja Puskesmas Mangkang Tahun 2015.

Hubungan Dukungan Keluarga dengan Tingkat Kepatuhan Minum Obat Pada Penderita Tuberkulosis (TB) Paru BTA Positif di Wilayah Kerja UPT. Puskesmas Martapura 1 
Proporsi dukungan keluarga dengan kategori dukungan baik berjumlah 31 responden termasuk kategori patuh minum obat sebanyak 24 responden $(77,4 \%)$ dan tidak patuh sebanyak 7 responden $(22,6 \%)$. Proporsi dukungan keluarga dengan kategori dukungan kurang berjumlah 13 responden termasuk kategori patuh minum obat sebanyak 5 responden $(38,5 \%)$ dan tidak patuh sebanyak 8 responden $(61,5 \%)$.

Hasil analisa uji chi square diperoleh nilai $\mathrm{p}=$ $0,019<a=0,05$ pada tingkat kepercayaan 95\% menunjukkan bahwa ada hubungan antara dukungan keluarga dengan tingkat kepatuhan minum obat TB paru BTA positif di wilayah kerja UPT. Puskesmas Martapura 1. Menurut penelitian yang dilakukan oleh Chasanah (2016) di RS PKU Muhammadiyah Gombong tentang hubungan dukungan keluarga terhadap kepatuhan minum obat pasien tuberculosis paru di RS PKU Muhammadiyah Gombong bahwa ada hubungan yang signifikan antara dukungan keluarga dengan terhadap kepatuhan minum obat pada pasien TB paru di RS PKU Muhammadiyah Gombong dengan $\mathrm{P}$ value $=$ $0,0001, a=0,05$, dan $\times 2=10,519$.

Menurut penelitian yang dilakukan oleh Desy Fitri Maulidia (2014) tentang hubungan antara dukungan keluarga dan kepatuhan minum obat pada penderita tuberculosis di wilayah Ciputat tahun 2014 diperoleh hasil uji statistik $P$ value $=0,000<\alpha=0,05$ maka bermakna bahwa ada hubungan antara variabel dukungan keluarga terhadap variabel kepatuhan minum obat.

\section{KESIMPULAN DAN SARAN}

Sebagian besar responden yaitu sebanyak 29 responden $(65,9 \%)$ patuh dalam minum obat dansebanyak 15 responden $(34,1 \%)$ tidak patuh minum obat. Sebagian besar responden yaitu sebanyak 36 responden $(81,8 \%)$ menilai peran petugas kesehatan dengan kategori baik dan sebanyak 8 responden $(18,2 \%)$ menilai peran petugas kesehatandengan kategori kurang. 3.Sebagian besar responden yaitu sebanyak 31 responden $(70,5 \%)$ dukungan keluarga dengan kategori dukungan baik dan sebanyak 13 responden (70,5\%) dukungan keluarga dengan kategori dukungan kurang.
Ada hubungan yang signifikan antara peran petugas kesehatan dengan tingkat kepatuhan minum obat TB paru BTA positif di wilayah kerja UPT. Puskesmas Martapura 1 dengan nilai ( $\mathrm{P}$ value $=0,001$ $<\alpha=0,05$ ). Ada hubungan yang signifikan antara dukungan keluarga dengan tingkat kepatuhan minum obat TB paru BTA positif di wilayah kerja UPT. Puskesmas Martapura 1 dengan nilai $(P$ value $=$ $0,019<\alpha=0,05)$.

\section{DAFTAR PUSTAKA}

A. Potter, \& Perry, A. G. 2007. Buku Ajar Fundamental Keperawatan: Konsep,. Proses, Dan Praktik, edisi 4, Volume.2. Jakarta: EGC.

Rumah Sakit Umum Cibabat. Cimahi , 1-9.

Departemen Kesehatan RI. 2006. Pedoman Nasional Penanggulangan Tuberkulosis Ed.2. http//tbindonesia.or.id/pdf/BUKU PEDOMAN NASIONAL.pdf Diakses pada tanggal 20 Mei 2018.

Depkes RI. 2007. Pedoman Nasional Penanggulangan Tuberkulosis. Jakarta; Direktorat Jendral Bina Kesehatan Masyarakat.

Depkes. R.I. 2008. Pedoman Nasional Penanggulangan Tuberkulosis. Cetakan Kedua.Jakarta : Bakti Husada.

Dinas Kesehatan Kabupaten Banjar. 2017. Data Kasus BTA +, Seluruh Kasus TB, Kasus TB pada Anak, dan CNR per 100.000 Penduduk Menurut Jenis Kelamin, Kecamatan, dan Puskesmas Kabupaten Banjar Tahun 2017. Martapura.

Dinas Kesehatan Kabupaten Banjar. 2017. Penyakit TBC.

http://www.depkes.go.id/resources/downlo ad/info-terkini /materi \%20pra \%20rakerkesnas\%202018/Pakar\%20TBC.pdf diakses pada tanggal 10 Mei 2018.

Eliska. 2005. Pengaruh Karakteristik Individu, factor pelayanan kesehatan, dan peran pengawas menelan obat (PMO) terhadap kepatuhan berobat penderita TB di Puskesmas Teladan Medan Tahun 2005. Skripsi, FKM USU. Medan.

Notoatmodjo, Soekidjo. 2007. Pendidikan dan Perilaku Kesehatan. PT. Rineka Cipta, Jakarta.

Notoatmodjo, Soekidjo. 2010. Metodologi Penelitian Kesehatan. Jakarta: Rineka

Cipta.

Riskesdas. 2013. Prevalensi Penyakit TBC. Jakarta http://www.depkes.go.id/resources/downlo ad/general/Hasil\%20Riskesdas\%202013.pdf. Diakses pada tanggal 2 Mei 2018.

Snewe, F. 2002. Faktor-Faktor yang Mempengaruhi Kepatuhan Berobat Penderita Tuberkulosis Paru. Depok : Peneliti Puslitbang Ekologi Kesehatan. 
Badan Litbangkes, bul. Panel.kesehatan, vol. 30, No.(1) : 31-38.

Sugiono. 2014. Faktor-Faktor Yang Berhubungan Dengan Tingkat Kepatuhan Mengkonsumsi OBAT Pada Penderita Tuberculosis Paru Di Puskesmas Sepauk Kabupaten Sintang Tahun 2014. Skripsi Sarjana Keperawatan. Sekolah Ilmu Kesehatan Kapuas Raya (STIKARA), Sintang.

Suparyanto, 2010. Konsep Kepatuhan. http://drSuparyanto.blogspot.com/2010/07/ konsep-kepatuhan.html. Diakses pada tanggal 18 Mei 2018.

UPT. Puskesmas Martapura 1. 2017. Laporan Bulanan UPT. Puskesmas Martapura 1 Tahun 2017. Kabupaten Banjar.

UPT. Puskesmas Martapura 1. 2018. Laporan Bulanan UPT. Puskesmas Martapura 1 Tahun 2018. Kabupaten Banjar.
UPT. Puskesmas Martapura 1. 2015. Laporan Tahunan UPT. Puskesmas Martapura 1 Tahun 2015. Kabupaten Banjar.

UPT. Puskesmas Martapura 1. 2016. Laporan Tahunan UPT. Puskesmas Martapura 1 Tahun 2016. Kabupaten Banjar.

UPT. Puskesmas Martapura 1. 2017. Laporan Tahunan UPT. Puskesmas Martapura 1 Tahun 2017. Kabupaten Banjar.

Videbeck, Sheila L. 2008. Buku Ajar Keperawatan Jiwa. Jakarta : EGC

Yuniar, Isma., Sarwono dan Astuti, Sri. 2017. Pengaruh PMO dan Dukungan Keluarga Terhadap Tingkat Kepatuhan Minum Obat TB Paru di Puskesmas Sempor 1 Kebumen. Jurnal.Universitas Muhammadiyah Magelang. http://elib.stikesmuhgombong.ac.id/703/1/U RECOL \%20ISI-min.pdf diakses pada tanggal 29 Maret 2018. 